\title{
NEPALESE INITIATIVES IN POVERTY RESEARCH: MOVING FROM UNI-TO-MULTIDIMENSIONAL CONCEPTS AND MEASUREMENTS
}

\begin{abstract}
Keshab Prasad Adhikari*
The aged long conventional unidimensional definition and measurement of poverty 'lack of money' in most countries is being replaced by the multidimensional approach and methodology. The launching of MPI report in 2018 implied Nepal also officially to adopt this in national poverty measurement policy strategy. This paper is aimed at to sensitize methodological aspects of MPI among academic and policy implications in Nepalese context. Debate on multidimensional poverty research in addressing rampant poverty dates back the advent of basic-needs and the physical quality of life index approaches of 1970s but both failed to establish a valid and reliable deprivation score to divide population as poor and non-poor like in income line approach. Human development index gave basis to rank countries into four groups as very high, high, medium and low level of human development. However it could not offer a precise deprivation score to divide population into-two as in absolute deprivation and non-deprivation as well as population in borderline of deprivation as alternatives of income poverty. It is the Alkire and Foster's (2007 and 2010) MPI methodology/approach of OPHI and successively adopted in human development reports of UNDP, aggressively being adopted as alternatives of conventional income line methods of poverty measurement and targeting policies. Three dimensional and ten indicators equally weighted MPI based on the same conceptual groundings of 'capability, wellbeing and functions' of Sen are taken as reliable alternative to the conventional income approach of poverty measurement. With the official release of national MPI study report in January 2018, Nepal adopted MPI in its policy option in targeting population living in multiple web of poverty and their targeting. The study found poverty and deprivation studied from MPI perspective is vital to attain multiple goals of 2030 SDGs.
\end{abstract}

Keywords: Poverty, multidimensional-poverty, capability, well-being andliving-standard.

\section{INTRODUCTION}

Poverty research initiatives in Nepal dates back to the decade of 1970s. Until the mid-half of the second decade of $21^{\text {st }}$ century, income line or 'cost of basic needs'(CBN) approach and methods remained as dominant one in poverty research in the country. The basic needs approach took attention during decades of late 1970s and early 1980s to address the severity of poverty/deprivation. However it could not offer a single composite to measure multidimensionality of poverty. The launching of first human development report by UNDP in 1990 opened-up avenues to member states for measuring level of deprivation of their populations devising a composites of sets of capabilities ${ }^{1}$ (beings) and functioning (doing) ${ }^{2}$ and thereby well-being. Nepal also prepared and launched its country specific human development reports periodically determining human development indices for sub-national populations (rural/urban, ecological

* Dr. Adhikari is Associate Professor at Central Department of Population Studies (CDPS), Tribhuvan University, Kirtipur, Kathmandu, Nepal.

1 Life expectancy at birth as proxy of health capability, school enrolment rate and achieved level of education as knowledge capability.

2 GNP per-capita measured in \$PPP as proxy of functioning and outcome of doing. 
zones and development regions, caste/ethnicity and the like). However, it could not replace the mainstream poverty/deprivation researchapproach. The poverty and human development initiatives of Oxford University (OPHI) in 2010 estimated 65 percent of Nepali population as multidimensionally poor (Alkire \& Santos, 2010) against 31 percent of nationally accepted poverty line (CBS, 2005). This stark difference between income-line and multidimensional approach of measuring poverty compelled policy and planning level for considering to incorporate multidimensional approach of poverty study in the country. Accordingly the 25 percent of population living below income poverty line estimated by Nepal Living Standard Survey 2010/11 (CBS, 2012) for the first time replaced by the estimates of 28 percent population to be in the web of multidimensional poverty by the year 2014 as shown by National Planning Commission (NPC) and OPHI study of 2018 from the data of Multiple Indicators Cluster Survey-2014.

\section{Objectives and data}

Objective of this paper is to review Nepalese initiatives of poverty research and growing shift in its dimensions from income line to multidimensional approaches. It uses secondary information from published and unpublished sources and then attempted to claim the essence and logic for poverty research to broaden its scope moving from uni-to-multidimensional approach. Since,most important development of poverty research in recent years is certainly the shift of emphasisfrom a uni-to-multidimensional approach to poverty.

\section{RESULTS}

\section{The MPI: Genesis and essence}

During the past (four) decades, there has been a discernible trend for defining poverty approaches, shifting from a narrow and static focus on incomes and consumption to recognition of poverty as a multidimensional phenomenon. In addition to aspects of 'physical deprivation', the broader sense of poverty encompasses non-material factors pertaining to 'social deprivation' such as self-esteem, respect, power and vulnerability. Now poverty study has shifted from an objectively-determined, material entity solely to recognition of subjective experiences and the processes to capture such experiences into a single framework of poverty discourses i.e. multidimensional. Borrowing from Baulch (1996), it seems useful to schematize the range of poverty concepts that are discussed in the literature using a pyramid to denote growing points in poverty research moving from uni-tomultidimensional ones (Figure 1).

Figure 1: A pyramid of poverty concepts

\begin{tabular}{|lc|}
\hline 1 & $\mathrm{PC}$ \\
2 & $\mathrm{PC}+\mathrm{CPR}$ \\
3 & $\mathrm{PC}+\mathrm{CPR}+\mathrm{SPC}$ \\
4 & $\mathrm{PC}+\mathrm{CPR}+\mathrm{SPC}+$ Assets \\
5 & $\mathrm{PC}+\mathrm{CPR}+\mathrm{SPC}+$ Assets + Dignity \\
6 & $\mathrm{PC}+\mathrm{CPR}+\mathrm{SPC}+$ Assets + Dignity + Autonomy \\
\hline
\end{tabular}

Note: $P C=$ Private consumption/income, $C P R=$ common property resources, $S P C=$ denotes stateprovided commodities.

Source: Baulch, 1996. 
The traditional income/consumption approach of poverty focuses on line 3 of this pyramid such as private consumption (PC), common property resources (CPR) and state-provided commodities (SPC)) but often settles in PC due to the difficulties of measuring consumption of state-provided commodities and access to common property resources (Baulch, 1996).Line 4 adopts a somewhat broader definition which aims to capture the vulnerability of the poor by including assets (such as human and physical capital, stores, and claims). Although a one-to-one correspondence does not exist between poverty and vulnerability, poor people generally have few assets and reach the threshold of collapse faster than the more affluent. The addition of dignity and autonomy embodies broader meanings of poverty including people's freedom (Baulch, 1996).

Poverty can be analyzed in terms of actual levels of deprivation. Chambers (1995) and Kabeer (1994) developed the idea to look deprivation at the whole spectrum of poverty i.e. devoid of basic human needs. Income/consumption poverty line approach ${ }^{3}$ defines poverty as low income. Both devoid of basic human needs and approaches explain poverty as 'deprivation and ill-being;' and for measurement and comparison (Chambers, 1995) its magnitudes.

Two concepts and measures of well-being viz. the physical quality life index (PQLI) by Moris D. Moris in 1976 and the Human Development Index (HDI) by UNDP in 1990have been accorded to be the most explicit attempts at an international comparison. Both concepts are built on the philosophy of Sen's 'capability and well-being'. In both health and educational achievements are taken as proxies of capability development. The PQLI is weighted sums of life expectancy at age one, the infant survival rate and the adult literacy rate. The concept drops the importance of income in measurement of quality of life or standard of living. The concept and construction of Human Development Index after eleven years of the introduction of PQLI by UNDP, is unwillingly taken as further improvement in Mori's work (Dasgupta, 1993; Srinivasan, 1994; Bardhan \& Klasen, 1999). The first Human Development Report (HDR, 1990) defined human development as 'the process of widening people's choices and the level of their achieved wellbeing' (Srinivasan, 1994) and introduces composite Index of Human Development (HDI)as the sum of certain normalized indices of per capita national income, life expectancy at birth and the adult literacy rate ${ }^{4}$. Human development concept build on the notion that 'primary objective of development is to benefit people, and income is not the sum total of human life'. The HDI is constructed to capture the three essential components of human life: longevity, knowledge and basic income for decent living standard. Longevity and knowledge refer to the formation of human capabilities, and income is a proxy measure for the choices people have in putting their capabilities to use. HDI is the equally weighted sum of deprivation of a country with respect to each of three components: life expectancy at birth, years of schooling and real income per head (Srinivasan, 1994).

The Sen's works vividly underpinned the concept and measures of human development, has argued powerfully for the need to take a multidimensional approach of study and measurement of poverty. His assertion is that 'human lives are battered and diminished in all kinds of different ways, and the first task... is to acknowledge that deprivations of very different kinds have to be accommodated within a general overarching framework' (Sen, 2000). Sen's perspective has implications for poverty and well-being measurement from new and emerging multidimensional frameworks. Taking footsteps on the Sen's pluralistic notion of concepts and measurement the Oxford Poverty and Human Development Initiative (OPHI) introduced concepts and measures of

3 Income based poverty line approach- also known as head count index.

4 In current years it has been upgraded to 'years of schooling' through adjustment of two 'mean years of schooling' and 'expected years of schooling'. 
'Multidimensional Poverty Index (MPI)' in 2010 a cogent and coherent framework for the measurement of poverty and wellbeing. MPI approach is claimed to forward a comprehensive definition and measure of acute multidimensional poverty and to reflect deprivations in very rudimentary services and core human functioning (Alkire \& Santos, 2010). MPI reveals a different pattern of poverty than income poverty, as it illuminates a different set of deprivations. The MPI has three dimensions: health, education, and standard of living and measures levels of deprivations or well-beings using ten indicators. Each dimension is equally weighted; each indicator within a dimension is also equally weighted. The MPI reveals the combination of deprivations that batter a household at the same time. A household is identified as multidimensionally poor if, and only if, it is deprived in some combination of indicators whose weighted sum is 30 percent or more of the dimensions.

The capability approach is widely taken as a broad normative framework for the evaluation and assessment of individual well-being and social arrangements. It can be used to see several aspects of people's well-being, such as inequality, poverty, the well-being of an individual or the average well-being of the members of a group (Robeyns, 2005). The perspective takes expansion of individual's choices through 'capability expansion' as both means and ends of human 'well-being'. It takes satisfaction of individual's basic needs as 'ends' and the endowments and entitlements a person has as 'means' of poverty analysis. Both means and 'ends' for the personal 'well-beings' are determined by the capability she/he exercises in life - that is denoted in multidimensional wellbeing of an individual, family and society.

The 2030 development agenda - 17 sets of Sustainable Development Goals (SDGs) acknowledges the eradication of poverty of all forms and dimensions. The first and foremost is eradiation of extreme poverty - the greatest global challenge and an indispensable requirement for achieving sustainable development goals. Good health and wellbeing, quality education, gender equality and clean water and sanitation are considered integral to attainment of individual and social wellbeing and to alleviate multidimensional poverty.

Sabina Alkire (2018), the proponent of MPI concepts and methods sees 'with the advent of the Sustainable Development Goals (SDGs), multidimensional poverty approach is graduating from the margins to the mainstream poverty research'. First of all, SDG framed multidimensionally, since the 17 goals and 169 targets ... are integrated, indivisible and balance with the three dimensions of sustainable development: the economic, social and environmental' (Alkire, 2018).The most important development of poverty research in recent years certainly is the shift of emphasis from uni-to a multi-dimensional approach. Poverty now within the SDG framework is defined as a human condition that reflects failures in many dimensions of human life such as hunger, ill health, malnutrition, unemployment, inadequate shelter, lack of education, vulnerability, powerlessness, social exclusion and poverty is not only multidimensional but also growing as multidisciplinary. Adam Smith defined poverty as "the impossibility to satisfy the needs that worthy people, even from the lower social ranks, could not do without, according to the uses of the country in which they live" (as cited in Guzman, 2005). Three main approaches most commonly identified in analysing the concept of poverty are:

Poverty as deprivation - poor is those who are deprived of the essential needs - termed as the state of absolute poverty.

Poverty as exclusion- the poor are those who are excluded from basic human and civil rights, lack of resources, and relations and wider community networks (de Hann \& Maxwell, 1998) from what is considered the usual way of life in the community or country where they live - termed as relative poverty. 
Poverty as dissatisfaction -the poor are those who feel that their income level does not allow them to access to what they consider the minimum living standards - termed as subjective poverty.

Measuring poverty consists basically in providing two figures: the number of poor in the population and the intensity of this poverty, or poverty gap. The reference for the calculation of these two figures is determination of a poverty line. The income or consumption line approach determines the level of income or consumption expenditure and themultidimensional approach determines the composite of level of wellbeing, below which an individual is classified as poor. The proportion of population below the poverty line then provides the incidence of poverty. Poverty gapis the difference between the poverty line and the real income enjoyed by the individuals classified as poor - and measures the intensity of this poverty, that is, how poor these poor are, or how far they are from reaching the line.

In practice, there are at least three broad types of definitions and indices of poverty measurements as (i) a person's current and prospective real income- inclusive of certain non-marketed goods and services, (ii) her/his current and future states of health, and (iii) her/his educational attainments. These three are the different categories of goods: where, health and education are an embodiment of positive freedoms, and income contributes to the enjoyments of these freedoms (Dasgupta, 1993). The three indicators, real-income, health and education are viewed to capture in their various ways a number of constituents indictors of poverty/development discourses. The income line analyses material aspects of poverty/wellbeing whereas health and education captures the multidimensional or capability aspects of human poverty.

\section{Nepalese practice to measure income poverty}

The government of Nepal introduced Basic-Needs approach of development planning for the period of late 1970s and during 1980s. Rationale behind the initiation was to overcome the inability of implementation of various development plans to ensure minimum quality of life for the people. The Seventh five year Development Plan (1986-90) was formulated with this approach. The bundles of basic needs identified were food, clothing, fuel wood, drinking water, peace and personal security, primary health care services and sanitation, basic education and skill and minimum rural transportation facilities. To attain these needs the strategy adopted include development of agriculture, water resources industry, trade and tourism (NSAC, 1998).

Nepal established its practices to construct poverty line using the cost-of-basic-needs (CBN) methods since 1995-96 (Nepal Living Standards Survey NLSS - I). The estimation of poverty in NLSS-II (2003/04) and III (2011) is based on the same methodology that of the NLSS-I. According to the CBN approach, the poverty line is defined as the expenditure value (in local currency) required to an individual to fulfil her/his basic needs in terms of both food and non-food items. The poverty line for the 2003-04 (NLSS II) round was an update of prices for the same basic needs basket estimated for the 1995-96 (NLSS I). In case of 2010-11 (NLSS-III) the poverty line is estimated based on a new basic needs basket of the poor to reflect changes in wellbeing over time (CBS, 2011).

The overall poverty line in Nepal is being obtained by aggregating the food and the non-food poverty line. The food basket of the poverty line is constructed by estimating how much the poor spend to maintain a minimum caloric requirement of 2,220 Kcal per day. The minimum caloric requirement was estimated considering composition by age and sex of an average Nepalese household and using the recommended dietary allowances by age-gender groups. Practically, the non-food allowance was estimated considering the share of non-food consumption (to total consumption) of households with per-capita food consumption close to the food poverty line in 
each of the analytical domains. Combining food and non-food consumption expenditure in local prices, the 2010-11 round survey (NLSS-III) on average determines poverty line for Nepal, at Rs. 19,261. The food poverty line is Rs. 11,929 and the non-food poverty line Rs. 7,332. According to the revised poverty line, the poverty incidence (headcount rate) for Nepal in 2010-11 is 25.2 percent, with much lower rate in urban areas $(15.5 \%)^{5}$ than in rural areas (27.4\%).

The proportion of poor population in 2003/04 was 31 percent and it was again high by 11 percentage points (42\%) for the year 1995/96. This implied that the incidence of poverty in Nepal declined by about 11 percentage points over the course of the first eight years (in between NLSS-I and NLSS-II) declining by 3.7 percent per year, and by about 6 percentage points for the six years period in between 2003/04 and 2010/11 (CBS, 2011a, 2005; World Bank, 1998). Trends in the incidence of poverty by urban rural residence in Nepal since 1977 to 2010/11 presented in Table 3.4 clearly envisaged that poverty level in Nepal after 1995/96 is declining consistently. The overcrowding of poverty incidences to the rural areas seem started to shift to the urban areas for the latest period of observation.

Table 1: Trends in poverty in Nepal estimated as head count index

\begin{tabular}{|llrrc|}
\hline \multirow{2}{*}{ Year of estimates } & \multirow{2}{*}{ Source } & \multicolumn{3}{c|}{ Incidence of poverty (\% poor) } \\
\cline { 3 - 5 } & & Rural & Urban & National \\
\hline 1977 & NPC* & 37.2 & 17.0 & 36.2 \\
1985 & MPHBS/NRB & 43.2 & 19.2 & 42.5 \\
1999 & WB/UNDP & 42.0 & 15.0 & 40.0 \\
$2003 / 04$ & CBS-NLSS-I & 43.3 & 21.6 & 41.8 \\
$2010 / 11$ & CBS-NLSS-II & 34.6 & 9.6 & 30.9 \\
\hline
\end{tabular}

*The minimumcalorie requirement per person was 2,256 kcals.

Source: NSAC, 1998; CBS, 2005, 2011.

Analysis of poverty profile made from 2010/11 NLSS revealed that high variation in poverty exists by sub-regions of considered analytical domains. Lowest headcount incidence of poverty is in hill urban regions and it is highest to the Mountain regions (42.2\%). Poverty has seasonal characteristics. Most poverty afflicted seasons is February to May and its incidence is lower during October to January.

Poverty incidence increases consistently with increase in household size and number of children under age 6. Opposite to expectation, incidence of poverty to the female headed households appeared to be lower compared to male headed ones (CBS, 2011a). It might be explained by more proportion of male from female headed households involved in foreign labour migration and sending remittance in regular basis. Poverty again is negatively correlated with attained educational level of households. Its sensitivity is further high in case of female literacy/ education.

\section{Multidimensional poverty}

Poverty always is understood as a multidimensional problem (Alkire and Santos, 2013), but traditionally is being measured with unidimension i.e. income poverty. Income approach of poverty is assumed to capture people's ability to achieve certain minimum thresholds in a variety of dimensions such as nutrition, clothing and housing. However, perceived insufficiency of income poverty measures to capture all forms of deprivation is a growing consensus. Income measure is short of addressing imperfection of market functioning and may fail to identify the need

5 Though increased 9.6 percent for the year 2003/04. 
of non-market goods and services (institutions) as a response of market imperfection such as drinking water and sanitation and health and education. Level of deprivation from such nonmarket goods then is believed be incorporated in the approach and methodologies of MPI known as Alkire and Foster's (AF) method. Multidimensional Poverty Index (MPI) designed by the Oxford Poverty and Human Development Initiative (OPHI) at the University of Oxford in 2010 and subsequently owned and published by the United Nations Development Program in its human development reports growingly is being adopted in national official MPI based on AF methodology. Nepal officially adopted it as national MPI since January 2018.

Designing multidimensional measures in the sense of Alkire (2018) requires the selection of following various parameters as:

Dimensions - Conceptual categories in which indicators are grouped for ease of communication, which often are equally weighted.

Indicators - Empirical data reflecting each person or household's condition in a particular area, such as the material of their flooring, their source of water, their years of schooling or their employment conditions.

Deprivation cutoffs - Standards for identifying the minimum achievements in each indicator that must be attained in order for a person or household to be considered non-deprived: for example, having completed the years of schooling that are compulsory for that cohort in that country.

Relative values (weights) - How much should a given deprivation in one indicator contribute to an overall profile of poverty, relative to the other deprivations considered?

Poverty cut-offs - Standards showing the minimum share of weighted deprivations that a person must experience in order to be identified as poor. Note that several poverty cut-offs are normally reported (Alkire, 2018).

\section{Dimensions and relative weights of MPI}

To the sense of Alkire \& Santos (2010) the index of acute multidimensional poverty reflects deprivations in very rudimentary services and core human functioning for people. The MPI presents a different pattern of poverty than income poverty, as it combines different three set/dimensions of deprivations i.e. health, education and standard of living. To measure the multidimensional poverty ten indicators (two each of health and education and six of living standard) have been identified, assigned relative weights and used (Table 2). Each dimension is equally weighted and each indicator within a dimension is also equally weighted. A household is identified as multidimensionally poor if, and only if, it is deprived in some combination of indicators whose weighted sum is 30 percent or more of the dimensions. The dimensions, indicators, and deprivation criteria forwarded by AF methodology (2007, 2009) (Alkire and Santos, 2010), prescription made in technical notes of Human Development Report (UNDP, 2016) and modified use in Nepal National MPI Report (2018) is presented in Table 2.

Multidimensional poverty score is obtained by summing the deprivation scores for each indicator. A cutoff of 33.3 percent, which is equivalent to $1 / 3$ of the weighted indicators, is used to distinguish the poor and non-poor households. If a household's deprivation score is 33.3 percent or higher, the household and all family members of it are considered as multidimensionally poor. Households with deprivation scores in between 20 and 33.3 percent are categorized as near to multidimensional poverty or vulnerable to it and households with 50 percent or higher deprivation score are categorized as severely multidimensionally poor (UNDP, 2016). Multidimensional 
poverty index according to AF methodology is the product of headcount ratio, $H$, and intensity of poverty,A.

The headcount ratio, $H$, is the proportion of the multidimensionally poor in the population obtained as:

$$
H=\frac{q}{n}
$$

Here $\mathrm{q}$ is the number of people who are multidimensionally poor and $\mathrm{n}$ is the total population.

Table 2: The dimensions, indicators, deprivation thresholds and weights of the MPI used and prescribed in different studies

\begin{tabular}{|c|c|c|c|c|}
\hline \multirow[b]{2}{*}{$\begin{array}{l}\text { Dimension and } \\
\text { indicators }\end{array}$} & \multicolumn{3}{|l|}{ Deprivation if .... } & \multirow[b]{2}{*}{$\begin{array}{l}\text { Rela } \\
\text { tive } \\
\text { weig } \\
\text { hts }\end{array}$} \\
\hline & AF, Alkire,\& Santos, 2010 & UNDP, 2016 & NPC/OPHI, 2018 & \\
\hline $\begin{array}{l}\text { Health (33.3\%) } \\
\text { Child Mortality } \\
\text { Nutrition }\end{array}$ & $\begin{array}{l}\text { - any child has died in the } \\
\text { family in the reference } \\
\text { period } \\
\text { - } \text { any adult or child in the } \\
\text { family is malnourished }\end{array}$ & $\begin{array}{l}\text { - a child has died in the } \\
\text { household within the } \\
\text { five years prior to the } \\
\text { survey } \\
\text { - } \text { a household member is } \\
\text { malnourished }^{\mathrm{a}}\end{array}$ & $\begin{array}{l}\text { - any child has died in the } \\
\text { family during } 5 \text {-year period } \\
\text { preceding the survey } \\
\text { - } \text { any child for whom there is } \\
\text { nutritional information is } \\
\text { undernourished in terms of } \\
\text { weight for age }\end{array}$ & $1 / 6$ \\
\hline $\begin{array}{l}\frac{\text { Education }}{(33.3 \%)} \\
-\quad \begin{array}{l}\text { Years of } \\
\text { Schooling }\end{array} \\
- \\
\text { Child School } \\
\text { Attendance }\end{array}$ & $\begin{array}{l}\text { - no household member } \\
\text { has completed } 5 \text { years of } \\
\text { schooling } \\
\text { - } \text { any school-aged child is } \\
\text { out of school in years } 1 \\
\text { to } 8\end{array}$ & $\begin{array}{l}\text { - } \text { no family member has } \\
\text { completed at least six } \\
\text { years of schooling. } \\
\text { - } \text { any school-aged child } \\
\text { (up to grade 8) is not } \\
\text { attending school }\end{array}$ & $\begin{array}{l}\text { - no family member aged } 10+ \\
\text { has completed } 5 \text { years of } \\
\text { schooling } \\
\text { - } \text { any school-aged child is not } \\
\text { attending school up to the } \\
\text { age at which he /she would } \\
\text { complete class } 8\end{array}$ & $1 / 6$ \\
\hline $\begin{array}{l}\text { Living standard } \\
(33.3 \%) \\
\text { - } \quad \text { Electricity } \\
\text { - } \quad \text { Drinking water } \\
\text { - } \quad \text { Sanitation }\end{array}$ & 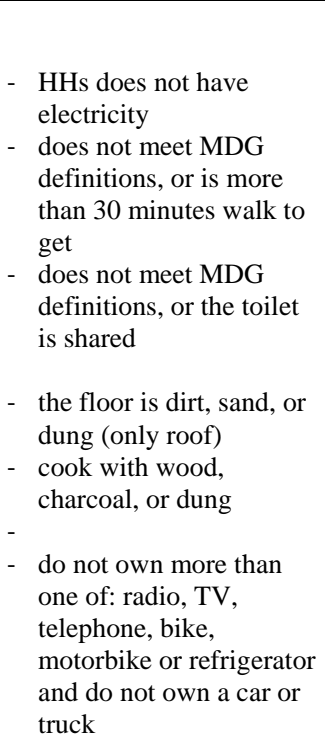 & $\begin{array}{l}\text { - HHs not having access } \\
\text { to electricity } \\
\text { - } \text { not having access to } \\
\text { clean drinking water } \\
\text { or is far awayc } \\
\text { - not having access to } \\
\text { improved sanitation } \\
\text { facilities or having it a } \\
\text { shared one } \\
\text { - home with dirt, sand } \\
\text { or dung floor } \\
\text { - using 'dirty' cooking } \\
\text { fuel (dung, wood or } \\
\text { charcoal) } \\
\text { not having more than } \\
\text { one asset related } \\
\text { access to information, } \\
\text { related to mobility and } \\
\text { related to livelihoodf }\end{array}$ & $\begin{array}{l}\text { - } \text { HHs has no electricity } \\
\text { - } \\
\text { - Same as others } \\
\text { - } \text { HHs sanitation facility is not } \\
\text { improved (as per MDG } \\
\text { guidelines) or it is shared d } \\
\text { - } \text { HHs poor in flooring and } \\
\text { roofe } \\
\text { - HHs cooks with dung, wood, } \\
\text { or charcoal } \\
\text { - HHs does not own more than } \\
\text { one of assets: radio, TV, } \\
\text { telephone, bicycle, } \\
\text { motorbike, or refrigerator, } \\
\text { and does not own a car or } \\
\text { truck }\end{array}$ & $\begin{array}{l}1 / 18 \\
1 / 18 \\
1 / 18 \\
1 / 18 \\
1 / 18 \\
1 / 18\end{array}$ \\
\hline
\end{tabular}


a as measured by the body mass index for adults (women ages 15-49 in most of the surveys) and by the height-for-age z-score calculated based on World Health Organization standards for children under age 5.

b Children are considered malnourished if their z-score of weight-for-age is below minus two standard deviations from the median of the reference population.

c having access to clean drinking water through a source that is located 30 minutes away or more by walking for round trip.

d A household is considered to have access to improved sanitation if it has some type of flush toilet or latrine, or ventilated improved pit or composting toilet, provided that they are not shared.

e has a dirt, sand, dung, or 'other' (unspecified) type of floor or has roof made of poor materials thatch/palm leaf, sod, rustic mat, wood planks, or 'other' (unspecified)

f Assets related to access to information include 'radio, television or telephone' related to mobility 'bike, motorbike, car, truck, animal cart or motorboat' and related to livelihoods refrigerator, arable land6 or livestock

The intensity of poverty, A, reflects the proportion of theweighted dimensional indicators in which, on average, poor peopleare deprived. For poor households i.e. households with deprivation score $c>=33.3$ percent, the deprivation scores are summed anddivided by the total number of poor people (family size of the deprived households) as:

$$
A=\frac{\sum_{i=1}^{n} c_{i}(k)}{q}
$$

where $\mathrm{c}_{\mathrm{i}}$ is the deprivation score that the $\mathrm{i}^{\text {th }}$ poor person experiences.

The deprivation score $\mathrm{c}_{\mathrm{i}}$ of the $\mathrm{i}^{\text {th }}$ poor person can be expressed as the sum of the weights associated with each indicator $\mathrm{j}(\mathrm{j}=1,2, \ldots, 10)$ in which person $i$ is deprived, $\mathrm{c}_{\mathrm{i}}=\mathrm{c}_{\mathrm{i} 1}+\mathrm{c}_{\mathrm{i} 2}+\ldots+$ $\mathrm{c}_{\mathrm{i} 10}$. The sequential flow of the computation process of MPI could schematically be expressed as in Figure 2.

Figure 2: Composition of multidimensional poverty index (MPI)

\begin{tabular}{|ll|l}
\hline Dimensions & Indictors \\
Health (2) & $\begin{array}{l}\text { Nutrition, } \\
\text { Cducation (2) }\end{array}$ & $\begin{array}{l}\text { Years of schooling } \\
\text { Children's school } \\
\text { enrolment }\end{array}$ \\
& $\begin{array}{l}\text { Cooking fuel } \\
\text { Toilet facility } \\
\text { Standard of }\end{array}$ & Water \\
living (6) & Electricity \\
& Housing condition \\
& Assets
\end{tabular}

Source: UNDP, 2016. 
The MPI value is the product of two measures: the multidimensional poverty headcount ratio and the intensity of poverty expressed as:

$$
\text { MPI }=\mathrm{HxA}
$$

\section{Multidimensional poverty in Nepal}

From the analysis of 2006 Nepal Demographic Health Survey data Alkire \& Santos (2010) estimated 65 percent of Nepali people afflicted of multidimensional poverty. The poor were deprived on average in more than half of the (weighted) indicators i.e. deprived in more than five of 10 indicators. Share of deprivation in living standard was the highest contributor of poverty, followed by health and education.

National Planning Commission in collaboration with Oxford Poverty and Human development Initiatives (OPHI) convened 'Nepal Multidimensional Poverty' study and derived MPIs for different sub-groups of population using the data from the Multiple Indicator Cluster Survey (MICS) 2014. Applying the Alkire Foster methodology to account global MPI, the study counted joint deprivations faced by individuals in the dimensions of multiple indicators of health, education, and living standards.

The study estimated 28.6 percent of Nepali population as multidimensionally poor. Unlike to the earlier estimates of 2010 (Alkire \& Santos, 2010), this study revealed declined share of deprivation in dimension of living standard and health (particularly undernutrition of children) and education (achieved years of schooling) found most to contribute in share of multidimensional poverty in the country. This indicated that still lives of Nepali people are battered by several deprivations simultaneously but it also reveals that Nepal actually halved its official MPI between 2006 and 2014, from 0.313 to 0.127 . Age wise disaggregated deprivation score showed that children aged 09 years are in the poorest age cohort, since, 42 percent of them found living in multidimensional poverty. This envisaged that children in Nepal are disproportionately affected by multidimensional poverty (NPC/OPHI, 2018), and in desperate need of addressing it.

The official launching of MPI study in Nepal is unique to present multidimensional deprivation scores (MPI) by seven provinces and urban rural areas (Table 3). It revealed seven percent of urban and one-third (33\%) of rural population as multidimensionally poor against 15.5 percent of urban and 27 percent of rural population falling below the poverty line based on income line approach. It further unveiled the fact that provinces 6 and 2 have the highest rate of multidimensional poverty - with every second person being multidimensionally poor (50\%) followed by Provinces 5 and 7 (approximately 30\%). Whereas the income line headcount index showed province seven to be the poorest (46\%) of all followed by province six (39\%) and Province two ranked as third poorest against ranking second in terms of multidimensional poverty scores i.e. MPI. 
Table 3: Reduction in MPI headcount in Nepal over the years and distribution of MPI by rural-urban and provinces, 2018

\begin{tabular}{|l|c|c|c|}
\hline $\begin{array}{l}\text { Source and year of } \\
\text { estimation }\end{array}$ & $\begin{array}{c}\text { Sources of data by } \\
\text { year }\end{array}$ & $\begin{array}{c}\text { MPI (Head count } \\
\text { index) }\end{array}$ & $\begin{array}{c}\text { CBN based headcount } \\
\text { index (NLSS-II \& III) }\end{array}$ \\
\hline 2010 (Alkire and Santos) & NDHS 2006 & 65.0 & 31.0 \\
2018 (NPC \& OPHI, 2018) & NDHS 2006 & 59.4 & 31.0 \\
2018 (NPC \& OPHI, 2018) & NDHS 2011 & 39.1 & 25.2 \\
2018 (NPC \& OPHI, 2018) & MICS 2014 & 28.6 & 25.2 \\
\hline 2018 (NPC \& OPHI, 2018) & Urban & 7.0 & 15.5 \\
MICS 2014 & Rural & 33.2 & 27.4 \\
\hline & Province 1 & 19.7 & 16.7 \\
& Province 2 & 47.9 & 26.7 \\
2018 (NPC \& OPHI, 2018) & Province 3 & 12.2 & 21.0 \\
MICS 2014 & Province 4 & 14.2 & 25.3 \\
& Province 5 & 29.9 & 38.6 \\
& Province 6 & 51.2 & 45.6 \\
\hline
\end{tabular}

\section{DISCUSSION AND CONCLUSION}

The perceived inability of unidimensional methodology of capturing whole gamut of human sufferings and the unfinished goal of basic-needs approach to com-up with an aggregated deprivation score, growingly drew the attention of researchers and policymakers alike to devise an alternative multidimensional poverty measure that exactly divides population into tow as poor and non-poor. This need is further fueled due, in part, to the compelling conceptual writings of Amartya Sen (Alkire \& Santos, 2010). It has been possible due to the unprecedented availability of relevant data. It equally needed development of a coherent framework for measuring poverty in the multidimensional environment that is analogous to the set of techniques developed in unidimensional space. As like to the unidimensionl measures, the multidimensional measure also needed to determine poverty line (deprivation score) i.e. headcount ratio $(H)$ and intensity of poverty (A). Applying the nested weighting approach, the AF methodology (2010) of counting multidimensional poverty (MPI) for the first time following the conceptual writing of Amartya Sen on human capability and functioning identified equally weighted three (health, education and living standard) dimensions of deprivation. Health and education are taken as capability dimensions and contains equally weighted two-each indicators, and the living standard captures dimensions of wellbeing and consists of equally weighted six dimensional indicators. A household if gets deprivation score in any one indicators of health or education and in three or more indicators of living standards is catogorized as multidimensionally poor, or if deprived in any two of four indicators of health and education also is poor. It implies, household getting 30 percent or more score is considered as multidimensionally poor. Instead, the income line approach tends changing the threshold level with time.

Aggregating the MPI follows the same methodology of accounting Human Development Index (HDI) i.e. assigning one-third weightage to all three (health, education and income dimensions of deprivation). However, HDI methodology do not prescribed a minimum deprivation cut-off score 
to divide national and sub-national populations as poor and non-poor, instead it ranked countries into four broad human development categories as Very High (above 0.8), High (HDI in between 0.70 and 0.79, Medium (HDI 0.55-0.69) and Low (HDI below 0.55) Human Development. With the invention of MPI, the pertinent deficiency of HDI to set a level of deprivation is viewed to be eliminated.

The cost of basic-needs (CBN) approach measures poverty as lack of command over basic consumption needs, and the poverty line is the cost of those needs. Which resembles only goal one of MDG-1 and SDG one and two (no-poverty and zero hunger). Whereas, MIP approach explicitly addresses four goals each of $\mathrm{MDGs}^{6}$ and $\mathrm{SDGs}^{7}$. Further MPI is gender sensitive, since deprivation in most indicators of living-standard dimension implies poor mitigation of practical gender needs of female in the family. It is also possible to compute MPI by age disaggregated manner such as MPI for child population, aged and the like. Hence, recent efforts have identified several classes of multidimensional poverty measures, discussed their properties, and raised important issues for future work.

\section{Acknowledgements}

Deep appreciation goes to the reviewer of the original article for her/his critical comments and feedback to improve it.

\section{REFERENCES}

Alkire, S.,\& Santos, M.E. (2013). A multidimensional approach: Poverty measurement and beyond. Social Indicators Research, 112(2), 239-257. Stable URL: http://www.jstor.org/stable/24719184,accessed on 26 May 2018.

(2010). Acute multidimensional poverty: A new index for developing countries. Working paper No. 38. Oxford:Oxford Poverty and Human Development Initiative (OPHI).

Alkire, S. (2018). The research agenda on multidimensional poverty measurement: Important and as-yet unanswered questions. Working Paper No.119.Oxford:Oxford Poverty and Human Development Initiative (OPHI).

Alkire, S., \&Foster,J. (2007). Counting and multidimensional poverty measurement.Oxford poverty and human development initiative. Working paper No. 7. Oxford: Oxford Department of International Development, University of Oxford.

Bardhan, K., \& Klasen, S. (1999). UNDP's gender-related indices: A critical review. World Development, 27(6), 985-1010. URL: www.elsevier.com/locate/wordldev,accessed on 21 March 2011.

6 Goal-2 universal primary education, goal-4 child mortality, goal-5 maternal mortality and goal-7 environmental sustainability.

7 Goal-3 good health and well-being, goal-4 quality education, goal-6 clean water and sanitation and goal-7 affordable and clean energy. 
Baulch, B. (2006). The new poverty agenda: A disputed consensus (editorial). Institute of Development Studies(IDS) Bulletin, 37(4), 82-90.

Central Bureau of Statistics (CBS). (2012). National population and housing census 2011. Vol. 1,National Report. Kathmandu: CBS.

(2011). Poverty in Nepal 2010/11. Kathmandu: CBS.

(2005). Poverty trends in Nepal 1995-96, 2003-04. Kathmandu: CBS.

(2004). Nepal living standard survey 2003/04. Vols. I \& II. Kathmandu: CBS.

Chambers, R. (1995). Poverty and livelihoods: Whose reality counts? Discussion paper No. 347. The Hague: Institution of Development Studies.

Dasgupta, P. (1993). An inquiry into wellbeing and destitution. Oxford: Clarendon Press.

de Hann, A.,\& Maxwell, S. (1998). Editorial: Poverty and social exclusion in north and south. Institute of Development Studies (IDS) Bulletin, 29(1),1-9.

Glewwe, P., \& Gaag, J.G. (1990). Identifying the poor in developing countries: Do different definitions matter? World Development, 18(6), 803-814.

Guzman, M.P. (2005). Population and poverty. Genus (Trends and problems of the world population in the XXI century, 50 years since Rome 1954), 61(3/4),167-184. URL:http://www.jstor.org/stable/29789273, accessed on 21 April 2018.

Kabeer, N. (1994). Beyond the poverty line: Measuring poverty and impoverishing measures (Chapter 6). In N. Kabeer (ed.)Reversed realities: Gender hierarchies in development thought. London \& New York: Verso, 136-162.

National Planning Commission, Nepal (NPC/Nepal) and Oxford Poverty and Human Development Initiative (OPHI). (2018). Nepal's multidimensional poverty index: Analysis towards action. Kathmandu: NPC/Nepal \& University of Oxford.

Nepal South Asia Centre (NSAC). (1998). Nepal human development report, 1998. Kathmandu: NSAC.

Notten, G.,\& De Neubourg, C. (2011). Monitoring absolute and relative poverty: 'Not enough' is not the same as 'much less'. Review of Income and Wealth, 57(2),247-269. Retrieved from SSRN: http://dx.doi.org/10.1111/j.1475-4991.2011.00443.x.

Ravallion, M., \& Bidani, B. (1994). How robust is a poverty profile? The World Bank Economic Review, 8(1),75-102. URL: http://www.jstor.org/stable/3989887, accessed on 21 August 2013.

Robeyns, I. (2005). The capability approach: A theoretical survey. Journal of Human Development, 6(1), 93-117. URL: http://dx.doi.org/10.1080/146498805200034266, accessed on 13 August 2012.

Sen, A. (2000a). A decade of human development. Journal of Human Development, 1(1), 17-23. URL: http://dx.doi.org/10.1080/14649880050008746,accessed on 18 August 2012. 
Srinivasan, T.N. (1994). Human development: A new paradigm or reinvention of the wheel? The American Economic Review, 84(2),238-243. URL: http://www.jstor.org/stable/2117836,accessed on 14 August 2012.

United Nations Development Programs (UNDP). (2016). Human development report, 2016: Human development for everyone (Technical notes). New York: UNDP.

World Bank. (1998). Poverty in Nepal: At the turn of the twenty-first century. Document of the World Bank. Report No. 18639-NEP. New York: World Bank. 